\title{
PERAN SOSIAL WANITA, ANTARA YANG MENGEKANG DAN MEMBEBASKAN
}

\author{
Abdul Hakim \\ Arief Suryadinata \\ Jurusan Kimia Fakultas Sains dan Teknologi UIN Maliki Malang \\ Telepon: 085931110750 \\ Jurusan Kimia Fakultas Sains dan Teknologi UIN Maliki Malang \\ Telepon: 081230745704
}

\begin{abstract}
The position of women in society is often regarded as second-class, making the backward condition and used as scapegoats for the backwardness of a society and nation. And even worse, the treatment of women by putting it as second-class communities are often mentioned as religious injunctions of Islam. On the other hand, there are those who want to empower women by giving women the freedom to freely, by demanding their equality with men in all aspects, without considering the differences that have been given by God to men and women. So what happens is the increasing number of family breakdown leading to divorce and loss of sosial community building. Hence the need for reconstruction of a fair idea about the position of women, both on the relationship of women with men, as well as the position and role of women in family and society. Based on observations of the hadiths of the Messenger of Allah, it was shown that a Muslim woman at the time (shahabiyah) has had a very complex role in the community. Nevertheless, they do not leave their primary role in the family and still uphold the ethics of religion in the publik domain.
\end{abstract}

Kedudukan wanita di masyarakat yang sering dianggap sebagai kelas dua, menjadikannya dalam kondisi terbelakang dan dijadikan sebagai kambing hitam bagi keterbelakangan suatu masyarakat dan bangsa. Dan lebih menyedihkan lagi, perlakuan terhadap wanita dengan meletakannya sebagai masyarakat kelas dua sering diopinikan sebagai perintah agama Islam. Di sisi lain, ada pihak yang ingin memberdayakan wanita dengan cara memberikan kebebasan kepada wanita sebebas-bebasnya, dengan menuntut persamaan mereka dengan laki-laki dalam semua aspek, tanpa mempertimbangkan perbedaan-perbedaan yang telah diberikan oleh 
Allah kepada laki-laki dan perempuan. Sehingga yang terjadi adalah semakin banyaknya keretakan keluarga yang berujung pada perceraian dan rusaknya bangunan sosial masyarakat. Oleh karena itu perlu adanya rekonstruksi pemikiran yang adil tentang posisi wanita, baik pada hubungan wanita dengan pria, maupun pada posisi dan peran wanita di keluarga dan masyarakat. Berdasarkan pengamatan terhadap haditshadits Rasulullah saw, ternyata menunjukkan bahwa wanita muslimah saat itu (shahabiyah) telah memiliki peran yang sangat kompleks ditengah masyarakat. Meskipun demikian, mereka tidak meninggalkan peran utama mereka di keluarga dan tetap memegang teguh etika-etika agama ketika berperan di wilayah publik.

Keywords: wanita, peran sosial, wilayah domestik, wilayah publik

\section{Pendahuluan}

Islam sebagai ajaran yang manusiawi, memberikan perhatian dalam porsi yang cukup besar tentang masalah wanita. Jika saja manusia mau menggunakan akal pikiran dengan jernih dan hati nuraninya dengan bersih, tentu ia akan mengakui kebenaran ajaran Islam sebagai agama fitrah/ manusiawi. Wanita dalam Islam diterjemahkan dalam dua kutub pendapat yang sangat bertolak belakang. Yaitu kutub yang melarang wanita untuk berkarya di luar rumah, dan hanya sebagai penerus keturunan, pendidik dan penanggung jawab rumah tangganya. Karenanya wanita dinomorduakan sampai dalam hal mencari ilmu, padahal justru dengan ilmu itulah wanita diharapkan mampu menjadikan rumah tangga berhasil mencetak generasi Islam yang tangguh. Sedang kutub yang berseberangan mengatakan wanita tidak ada bedanya dengan laki-laki. Wanita yang berkeluarga diharuskan mandiri dalam segi ekonomi agar dapat menyalurkan kehendaknya, bahkan seorang wanita diperbolehkan mengingkari kewajibannya sebagai ibu yang melahirkan demi karir di luar rumah untuk mewujudkan jati dirinya dan mengembangkan keperibadiannya (www.jaist.ac.jp, 2011). Bahkan ada juga feminis yang bersikap anti laki-laki, mengutuk sistem patriarki, mencemooh perkawinan, menghalalkan aborsi, merayakan lesbianism dan revolusi seks. Menurut mereka, seorang istri sama saja disandera. Tinggal bersama suami dianggap sama dengan living with the enemy (Arif, 2006: 93). 


\section{Pria dan Wanita}

Sebagai hamba Allah, semua manusia tidak memandang jenis kelamin (apakah pria dan wanita), suku dan bangsa--memiliki kedudukan yang sama. Dalam hal ini derajat manusia hanya diukur dengan standar takwa, yaitu sejauh mana ketundukan manusia pada ketentuan-ketentuan Allah. Allah berfirman:

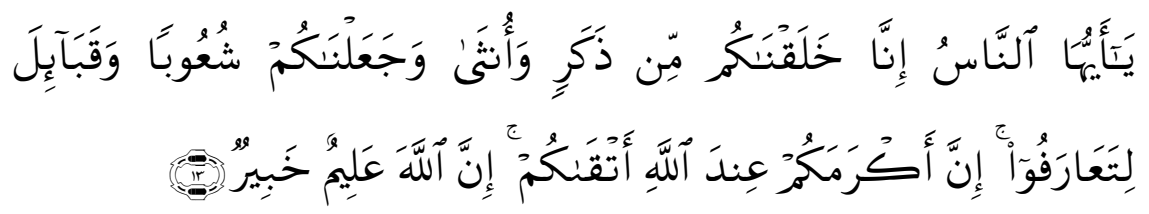

Hai manusia, sesungguhnya Kami menciptakan kamu dari seorang lakilaki dan seorang perempuan dan menjadikan kamu berbangsa - bangsa dan bersuku-suku supaya kamu saling kenal-mengenal. Sesungguhnya orang yang paling mulia diantara kamu disisi Allah ialah orang yang paling taqwa diantara kamu. Sesungguhnya Allah Maha mengetahui lagi Maha Mengenal. (QS Al-Hujurat:13)

Sementara manusia dalam posisinya sebagai laki-laki atau perempuan, Allah telah menetapkan bahwa keduanya memang memiliki perbedaan dalam struktur fisik, dengan tentunya seperangkat perbedaan (distinction) dalam hal potensi yang diberikan Allah kepada masing-masing jenis kelamin ini. Dalam hal ini, justru merupakan keadilan ketika Allah menetapkan adanya pembedaan (discrimination) dalam hal perlakuan hukum kepada laki-laki dan perempuan. Mereka memiliki misi dalam kehidupan ini yang sesuai dengan tabiat dan keahlian masing-masing, untuk suatu tujuan yang sangat besar dan mulia.

Menyikapi perbedaan hukum tersebut, Allah telah memerintahkan kapada pria dan wanita untuk sama-sama ridha terhadap adanya pengkhususan kepada salah satu pihak. Allah juga melarang bersikap saling iri dan dengki kepada pihak lain. Allah swt berfirman,

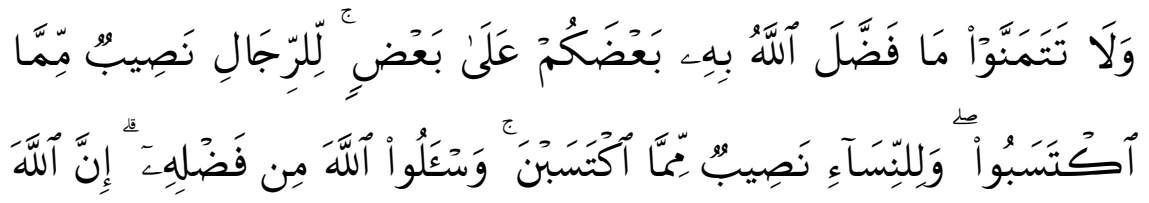




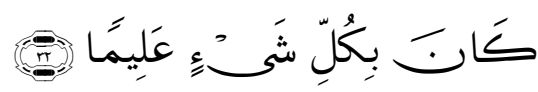

Dan janganlah kamu iri hati terhadap apa yang dikaruniakan Allah kepada sebahagian kamu lebih banyak dari sebahagian yang lain. (Karena) bagi orang laki-laki ada bahagian dari pada apa yang mereka usahakan, dan bagi para wanita (pun) ada bahagian dari apa yang mereka usahakan, dan mohonlah kepada Allah sebagian dari karunia-Nya. Sesungguhnya Allah Maha mengetahui segala sesuatu. (QS An-Nisa: 32).

Ada beberapa riwayat hadits yang mengungkapkan sebab turunnya ayat di atas. Dalam sebuah riwayat dari At-Tirmidzi dan Hakim dikemukakan bahwa Ummu Salamah berkata,'Kaum laki-laki berperang, sedangkan wanita tidak, dan kita hanya mendapatkan setengah bagian warisan laki-laki." Kemudian dalam riwayat lain dikemukakan bahwa seorang wanita mengadu kepada Nabi dengan berkata,"Ya Nabiyullah! Laki-laki mendapat dua bagian kaum wanita dalam waris dan dua orang saksi wanita sama dengan seorang saksi laki-laki. Apakah dalam beramal pun demikian juga (yaitu amal baik seorang wanita mendapatkan pahala setengah dari jumlah pahala laki-laki)?" Maka Allah turunkan ayat tersebut sebagai penegasan bahwa laki-laki dan wanita akan mendapatkan imbalan yang sama sesuai dengan amalnya (Dahlan, 2003: 129).

Sayyid Quthb menyampaikan dengan sangat indah tafsir tentang ayat ini. Islam selalu mengikuti fitrah dalam membagi tugas-tugas dan dalam menentukan bagian laki-laki dan wanita. Pada dasarnya merupakan fitrah menjadikan lelaki sebagai lelaki dan wanita sebagai wanita. Lalu memberikan kekhususan dan keistimewaan masing-masing untuk menyandarkan tugas-tugas tertentu kepada masing-masing pihak. Bukan untuk memberikan perhitungan khusus karena jenis kelaminnya, melainkan memperhitungkan kehidupan kemanusiaan yang ditegakkan dan diatur, yang dipenuhi kekhususan-kekhususan dan diwujudkan tujuannya dengan jalan diadakannya pembedaan jenis kelamin dengan beraneka macam kekhususannya dan fungsinya. Oleh karena itu, bervariasi pula beban-beban tugasnya, bagiannya dan fokusnya untuk memenuhi persekutuan terbesar dan organisasi teragung yang bernama kehidupan (Siti, 2006: 116).

Tidak ada agama seperti Islam yang memuliakan perempuan dalam setiap bidang dan setiap dimensi. Islam menghormati wanita sebagai 
seorang manusia, perempuan, putri, istri, ibu, dan anggota masyarakat. Sebagaimana firman Allah swt,

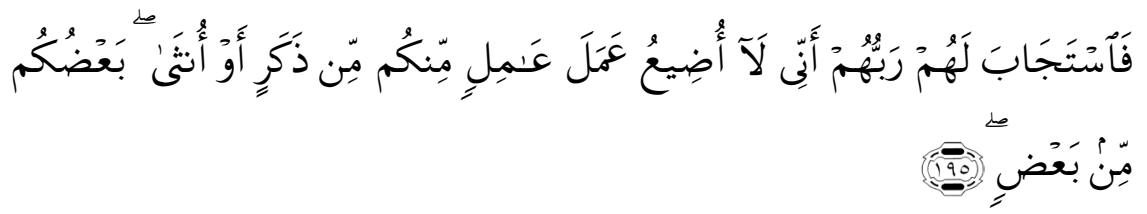

Maka Tuhan mereka memperkenankan permohonannya (dengan berfirman): "Sesungguhnya aku tidak menyia-nyiakan amal orang-orang yang beramal di antara kamu, baik laki-laki atau perempuan, (karena) sebagian kamu adalah dari sebagian yang lain. (QS. Ali Imran: 195)

Maksudnya adalah bahwa perempuan itu bagian dari laki-laki, dan laki-laki bagian dari perempuan. Laki-laki menyempurnakan perempuan, dan perempuan menyempurnakan laki-laki. Perempuan bukan musuh lakilaki dan laki-laki juga bukan lawan perempuan (Al-Qaradhawi, $2007 \mathrm{hlm}$ 245).
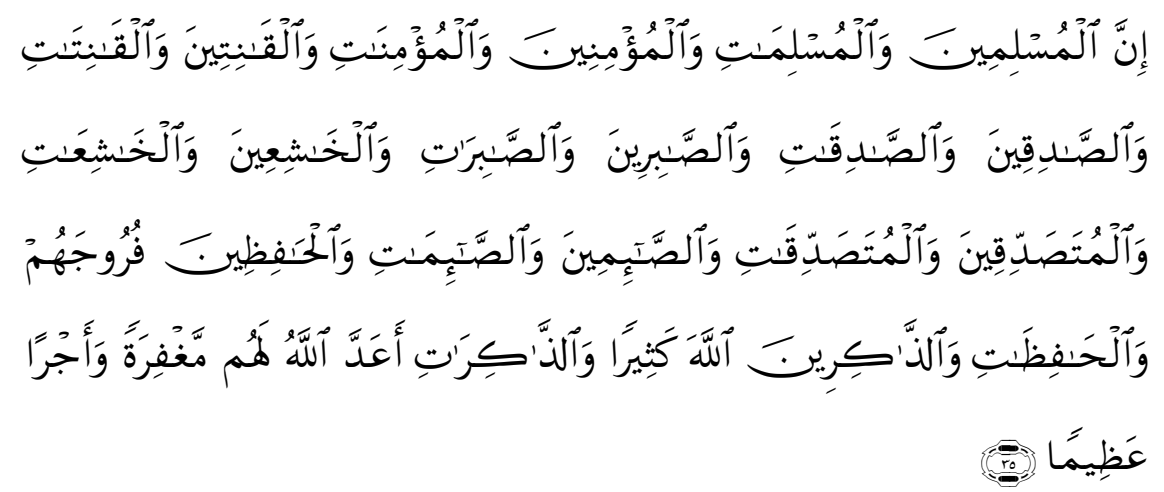

Sesungguhnya laki-laki dan perempuan yang muslim, laki-laki dan perempuan yang mukmin, laki-laki dan perempuan yang tetap dalam ketaatannya, laki-laki dan perempuan yang benar, laki-laki dan perempuan yang sabar, laki-laki dan perempuan yang khusyuk, laki-laki dan perempuan yang bersedekah, laki-laki dan perempuan yang berpuasa, laki-laki dan perempuan yang memelihara kehormatannya, laki-laki dan perempuan yang banyak menyebut (nama) Allah, Allah telah menyediakan untuk mereka ampunan dan pahala yang besar. (QS Al-Ahzab: 35) 
Ayat di atas menjelaskan bahwa yang penting bukan jenis kelaminnya, akan tetapi amal ibadah seseorang. Dari ayat-ayat dan penjelasan di atas, nampak sekali bagaimana Islam memuliakan wanita. Oleh karena itu, apabila di kalangan muslim pada kenyataannya masih selalu dijumpai diskriminasi terhadap perempuan, maka yang seharusnya dikoreksi adalah masyarakatnya, bukan agamanya. Hal ini dikarenakan pada kenyataannya, di tanah kelahirannya sendiri, gerakan feminis dan kesetaraan gender masih belum bisa menghapuskan sama sekali berbagai bentuk pelecehan, penindasan dan kekerasan terhadap perempuan. Berdasarkan hasil survey, kendati undang-undang persamaan upah (Equal Pay Act 1970) di Inggris sudah berusia 30 tahun lebih, wanita yang bekerja sepenuh waktu di negeri itu digaji 18\% lebih rendah dari pekerja laki-laki. Sementara mereka yang bekerja separuh waktu menerima upah 39\% lebih rendah berbanding lakilaki. Begitu juga di Amerika Serikat, pendapatan kaum wanita rata-rata 25\% lebih rendah dibanding laki-laki. Penelitian lain menemukan bahwa rata-rata dalam tiap 10 detik di Inggris telah terjadi kekerasan terhadap wanita, berupa pemukulan, pemerkosaan atau bahkan pembunuhan. Ini belum termasuk pelecehan seksual dan sebagaianya (Arif, 2006: 98).

\section{Wanita di Wilayah Domestik}

Pada dasarnya, Islam membagi kehidupan ini menjadi dua bagian, yaitu: (1) kehidupan umum (wilayah publik); dan (2) kehidupan khusus/ pribadi (wilayah domestik) (Siti, 2004: 121). Untuk mencapai tujuan kehidupan di dua wilayah tersebut, Allah telah menetapkan pembagian tugas, karena memang tujuan bersama di kedua wilayah itu hanya bisa dicapai secara efektif dan efisien, manakala ada pembagian tugas.

Islam menetapkan bahwa peran utama wanita sesuai dengan struktur tubuh dan potensinya adalah di wilayah domestik sebagai ibu dan pengatur rumah tangga. Pada diri perempuan, Allah menciptakan kemampuan reproduksi dan fungsi penentu keberlangsungan jenis manusia. Allah menjadikan tugas mengandung, melahirkan, menyusui, dan mengasuh anak pada mereka. Ini adalah tugas yang berat, tidak mudah dan penting, sekaligus mulia yang harus ditunaikan oleh wanita dengan persiapan fisik, kejiwaan dan pikiran yang mendalam. Bahkan, demi kesempurnaan penunaian tugas utama ini, Allah memberikan toleransi untuk berbuka di bulan Ramadhan bagi ibu hamil atau menyusui (Siti, 2004: 127). Sedangkan 
kewajiban mencari nafkah, berjihad dan aktifitas-aktifitas lainnya yang dilakukan di wilayah publik, dibebankan kepada pria karena sesuai dengan struktur tubuh dan potensi yang dimilikinya. Sebagaimana dijelaskan di atas, bahwa pembagian tugas antara pria dan wanita itu adalah supaya tercapai tujuan kehidupan ini. Masing-masing tugas tersebut sama-sama penting dan bernilai sama di hadapan Allah swt. Masing-masing pihak tidak diperbolehkan merasa lebih utama dan penting dibanding pihak lain. Dr. Lois Lamya (istri almarhum Prof. Isma'il Raji al-Faruqi) mengatakan bahwa gerakan feminis di kalangan muslim juga seyogyanya diletakkan dalam bingkai pembangunan umat secara keseluruhan, tidak chauvinistic dan hanya memikirkan kepentingan kaum wanita saja (Arif, 2006: 99).

Dalam sebuah riwayat disebutkan bahwa datang seorang wanita, Asma binti Yazid al-Asyhaliyah, yang mewakili kaumnya kepada Rasulullah saw. Ia menanyakan kedudukan dan tugasnya sebagai wanita kepada Rasul yang mulia.

"Demi bapakku, engkau dan ibuku, wahai Rasulullah. Aku adalah utusan para wanita kepadamu. Sesungguhnya belum ada seorang wanita pun, baik di timur maupun barat, yang terdengar darinya ungkapan seperti apa yang akan aku ungkapkan atau belum terdengar seorang pun yang mengemukakan seperti pendapatku. Sesungguhnya Allah mengutusmu kepada laki-laki dan wanita seluruhnya, hingga kami beriman kepadamu dan Tuhanmu. Akan tetapi, sesungguhnya kami, para wanita terbatasi oleh dindingdinding kalian (para lelaki), memenuhi syahwat kalian, dan mengandung anak-anak kalian. Sesungguhnya kalian, wahai para lelaki, mempunyai kelebihan dari pada kami dengan berkumpul dan berjama'ah, melakukan kunjungan kepada orang sakit, dan menyaksikan jenazah, menunaikan ibadah haji demi ibadah haji, dan yang lebih mulia lagi dibandingkan dengan semua itu adalah jihad di jalan Allah. Sesungguhnya jika salah seorang dari kalian keluar untuk menunaikan ibadah haji, menghadiri pertemuan, atau berjaga di perbatasan, kamilah yang menjaga harta kalian, yang mencucikan pakaian kalian dan yang mengasuh anak-anak kalian. Lalu apakah ada kemungkinan bagi kami untuk menyamai kalian (para lelaki) dalam kebaikan, wahai Rasulullah?” 
Kemudian Rasulullah saw menoleh kepada para sahabat seraya berkata,"Apakah kalian mendengar perkataan wanita ini? Sungguh, adakah yang lebih baik daripada apa yang diungkapkannya berkaitan dengan urusan agamanya ini?" Para sahabat berkata,"Wahai Rasulullah, kami tidak menyangka bahwa wanita ini tertunjuki kepada perkataan tersebut." Rasulullah lalu menoleh kepada wanita itu seraya bersabda,"Pergilah kepada wanita mana saja dan beritahukanlah mereka yang ada di belakangmu, bahwa kebaikan salah seorang di antara kalian (para wanita) dalam memperlakukan suaminya, dan mengikuti keinginannya adalah mengalahkan semua itu." Mendengar sabda Rasul, wanita itu pun pergi seraya bersuka cita. Ia kemudian menyampaikan kabar gembira itu kepada kaumnya. (HR AlBaihaqi).

Dialog Nabi saw dengan sahabiah di atas menunjukkan tugas utama wanita adalah sebagai ibu dan pengatur rumah tangga. Meskipun demikian, karena peran ini mempunyai andil yang sangat besar bagi terwujudnya masyarakat yang sejahtera dan generasi yang baik, maka penunaian tugastugas domestik ini memiliki penilaian yang sangat tinggi, setara dengan penilaian Allah kepada laki-laki yang berperan utama di dunia publik. Pembagian tugas antara laki-laki dan wanita yang disesuaikan dengan potensi alamiahnya yang telah diberikan oleh Allah, bisa diibaratkan lazimnya hubungan antar manusia. Ada yang berperan sebagai sopir, pelajar, dosen, tukang sapu, polisi, dan lain-lain. Masyarakat akan sejahtera dan mencapai tujuannya apabila masing-masing orang menjalankan peran/ profesinya sebaik mungkin dan bekerja sama antara satu dengan lainnya. Dan sebaliknya masyarakat akan kacau, bila semua anggota masyarakat berprofesi sama, karena menganggap profesi itu yang paling baik.

\section{Peran Sosial Muslimah}

Paparan di atas menjelaskan bahwa wanita memiliki peran utama di wilayah domestik, sedangkan pria memiliki peran utama di wilayah publik. Namun demikian, karena mereka laki-laki dan perempuan adalah sama-sama manusia yang ditunjuk oleh Allah sebagai khalifah di bumi, maka masing-masing pihak harus menjadi mitra kerja yang baik bagi pihak 
yang lain dalam memakmurkan bumi sesempurna mungkin. Sungguh benar apa yang disabdakan Rasulullah saw dalam hadits: "Kaum wanita adalah saudara kandung kaum pria (Shahih Al-Jami', As-Shagir no. 1979). Karena itu, wanita dengan tetap mengutamakan perannya di wilayah domestik haruslah ikut serta dengan serius dalam peran publik, dimana kiprah dan sepak terjang kewanitaannya selalu ditunggu oleh masyarakat yang selalu butuh sosok perempuan. Karena banyak sekali, bidang-bidang tertentu di wilayah publik membutuhkan peran serta kaum wanita. Seperti dokter kandungan, perawat, guru, dan lain sebagainya. Demikian juga sebaliknya kaum pria, meskipun peran utamanya di wilayah publik, tetap diperlukan perannya di wilayah domestik.

Sejak dahulu, keikutsertaan wanita dalam aktivitas sosial dan pertemuannya dengan kaum laki-laki, baik secara kebetulan maupun disengaja untuk suatu tujuan yang baik, sudah merupakan corak kehidupan yang umum dalam masyarakat muslim baik dalam bidang umum maupun khusus. Muslimah di zaman rasul, ternyata memiliki peran yang sangat kompleks di ranah umum (publik). Menurut Abu Syuqqah, terdapat lebih 300 buah hadits dengan sumber kitab Shahih Bukhari dan Muslim yang menerangkan keterlibatan kaum wanita dalam berbagai bidang kehidupan bersamaan dengan kehadiran kaum laki-laki (Abu Syuqqah, 1999: 15).

Mengutip definisi dari Abu Syuqqah, yang dimaksud kegiatan sosial di sini mencakup dua hal, yaitu: pertama, kegiatan yang dilakukan secara bersama. Artinya sejumlah orang bergabung dan bekerjasama melakukan sesuatu yang bermanfaat bagi diri mereka dan masyarakat umum, baik dalam bidang ibadah, keilmuan maupun hiburan. Kedua, kegiatan yang dilakukan oleh satu atau beberapa orang secara sukarela sebagai pengabdian terhadap masyarakat dalam bidang pendidikan, amar ma'ruf dan nahi munkar, kerja bakti, pengabdian sosial, serta kegiatankegiatan lainnya (Abu Syuqqah, 2000: 449). Berikut beberapa hadits yang menggambarkan keterlibatan wanita dalam berbagai kegiatan di zaman Rasulullah saw (Abu Syuqqah, 2000: 450-462):

1. Keterlibatan wanita dalam kegiatan memakmurkan masjid

a. Kegiatan ibadah.

Banyak sekali hadits yang menggambarkan bahwa para wanita muslimah zaman Rasulullah (shahabiah) ada yang menjalankan 
sholat fardlu, shalat sunnah, shalat jum'at, shalat jenazah dan sholat gerhana di masjid. Mereka juga tidak ketinggalan menjalankan I'tikaf di masjid pada bulan Ramadlan. Berikut beberapa contoh hadits:

Dari Abdullah bin Umar, dari Nabi saw, beliau bersabda:"Apabila istri-istri kalian minta izin malam hari untuk pergi ke masjid, maka izinkanlah mereka." (HR. Bukhari dan Muslim) (Kitab Bukhari).

Dari A'isyah ra, dia berkata:"Kami para tokoh muslimah hadir bersama Rasulullah saw untuk melaksanakan shalat fajar dengan menyelimuti sekujur tubuh dengan kain. Selesai shalat kami pulang ke rumah masing-masing dan tidak seorang pun yang mengenal kmai karena hari masih gelap.” (HR Bukhari dan Muslim) (Kitab Bukhari).

Dari Ibnu Abbas ra dikatakan bahwa dia berkata:'Sesungguhnya Ummul Fadhl mendengarnya ketika dia sedang membaca surat Warmulsatul urfa. Ummul Fadhl berkata,'Wahai anakku, demi Allah, bacaanmu terhadap surat ini mengigatkanku pada sesuatu. surat ini adalah surat paling akhir sekali aku mendengar Rasulullah saw membacanya waktu shalat magrib." Dan dalam satu riwayat dikatakan:"Kemudian setelah itu beliau tidak pernah lagi shalat bersama hingga Allah memanggilnya." (HR Bukhari dan Muslim) (Kitab Bukhari).

b. Kegiatan ilmiah.

Dari Zainab, istriAbdullah, dia berkata:"Aku berada dalam masjid, lalu aku melihat Nabi saw.. Beliau bersabda:'Bersedekahlah kalian, walaupun dengan perhiasan kalian....." (HR Bukhari dan Muslim) (Kitab Bukhari).

Dari Amrah binti Abdurrahman dari kakak perempun Amrah, dia berkata:"Aku mengambil (belajar) Qaaf. Wal Qur'anil Majiid (surat Qaaf) dari mulut Rasulullah saw ketika beliau membacanya di atas mimbar setiap jum'at." (HR Muslim) (Kitab Muslim).

Dari Fatimah binti Qais:".... Aku pergi ke masjid, lalu shalat bersama Rasulullah saw. Setelah Rasulullah saw selesai 
melaksanakan shalat, beliau duduk di atas mimbar. Sambil tertawa beliau berkata: "Hendaklah semua orang tetap di tempatnya." Kemudian beliau bertanya: "Apakah kalian tahu mengapa kalian aku kumpulkan?” Mereka menjawab: “Allah dan RasulNya lebih tahu." Beliau berkata: "Demi Allah, sesungguhnya aku mengumpulkan kalian tidak untuk suatu kegembiraan atau ketautan, akan tetapi aku kumpulkan kalian karena Tamim adDariy yang dulu seorang Nasrani telah datang untuk berbai'at dan masuk Islam. Dia menceritakan kepadaku satu cerita yang sesuai dengan apa yang pernah aku ceritakan kepada kalian mengenai masihd dajjal...." (HR Muslim) (Kitab Muslim).

c. Kegiatan hiburan.

Khaulah binti Qais berkata:"Pada masa Nabi saw, Abu Bakar dan permulaan masa Umar, kami kaum wanita bercanda dalam masjid. Barangkali ada sebagian kami yang menenun dan sebagian lagi menganyam daun-daun kurma. Lantas Umar berkata, "Akan aku keluarkan kalian.” Lalu Umar mengeluarkan kami dari masjid. Tetapi kami mengikuti shalat pada waktunya." (Ath-Thobaqot Kubro Jilid 8: 296)

2. Keterlibatan wanita dalam acara umum atau resepsi

a. Acara penyambutan tamu

Dari Abu Bakar ra, dia berkata:”... Kami sampai di Madinah pada malam hari. Maka orang-orang saling berselisih satu sama lain mengenai di tempat siapakah di antara mereka Rasulullah saw akan berhenti. Maka beliau berkata, "Aku akan berhenti di perkampungan Bani Najjar, pamannya Abdul Muthalib, dengan demikian aku menghormati mereka. "Kemudian kaum laki-laki dan wanita naik ke rumah, sedangkan para pemuda dan pelayan bertebaran di jalan sambil berseru: "Wahai Muhammad, wahai Rasulullah, wahai Muhammad, wahai Rasulullah!" (HR Muslim) (Kitab Muslim).

b. Keramaian hari raya

Dari Ummu Athiyah ia berkata: "Nabi saw memerintahkan kami supaya membawa keluar budak-budak perempuan yang telah 
dewasa dan gadis-gadis pingitan (ke tempat sholat "ied)." (HR. Bukhari dan Muslim) (Kitab Bukhari).

Dari Aisyah, ia berkata: "...Ketika itu adalah hari raya, di mana orang Sudan sedang bermain tameng dan tombak. Entah aku yang meminta atau Nabi sendiri yang berkata padaku: "Apakah kamu ingin melihatnya?" Aku jawab: "Ya." Aku disuruh berdiri di belakangnya, sementara pipiku menempel dengan pipinya. Nabi berkata: "Teruskanlah permainan kalian, hai Bani Arfidah. "Ketika aku telah merasa bosan, Nabi bertanya: "Cukup?" Aku menjawab: "Ya." Dan dalam satu riwayat: "Perkiraan lamanya semisal gadis remaja yang masih muda usai mendengarkan lagu." (HR Bukhari dan Muslim) (Kitab Bukhari).

c. Resepsi perkawinan

Dari A'isyah ra, ia berkata:"... kemudian datang menemuiku ibuku, Ummu Ruman, kemudiam dia membawaku masuk ke satu rumah. Begitu masuk aku lihat beberapa orang wanita Anshar sudah berada di dalamnya. Mereka menyambutku dengan mengucapkan: "Semoga kamu mendapatkan kebaikan, berkah dan keberuntungan!" Lalu ibuku menyerahkanku kepada mereka untuk didandani sebaik mungkin. Tidak ada yang membuatku lebih kaget selain karena ibuku menyerahkanku kepada Rasulullah saw waktu pagi ..." (HR Bukhari dan Muslim) (Kitab Bukhari). Hafizh Ibnu Hajar berkata bahwa Ahmad meriwayatkan dari jalur lain seperti berikut: Asyah berkata: "Ibuku membawaku masuk. Aku dapati Rasulullah saw sedang duduk di atas ranjangnya. Di sampig beliau ada beberapa orang laki-laki dan wanita Anshar. Lalu ibuku menyuruhku duduk di kamar Rasulullah saw, kemudian ibu berkata, "Mereka ini keluargamu wahai Rasulullah. Semoga Allah memberkahimu kepada mereka." Setelah itu lakilaki dan wanita tersebut berlompatan keluar. Lalu Rasulullah saw membangun kehidupan rumah tangga denganku di rumah kami." (Fathul Bari jilid 8: 224-225) 
3. Keterlibatan wanita pada kegiatan ilmiah di luar masjid

a. Rasulullah saw menyelenggarakan seminar ilmiah khusus untuk kaum wanita.

Dari Abu Sa'id al-Khudri, dia berkata bahwa seorang wanita datang kepada Rasulullah saw dan berkata: "Ya Rasulullah, kaum pria telah membawa haditsmu, maka tolonglah sediakan satu hari dari waktumu untuk kami." Rasulullah saw menjawab: "Berkumpullah kalian pada hari ini, hari ini." Maka berkumpullah mereka, lalu Rasulullah saw mendatangi mereka. (HR. Bukhari dan Muslim) (Kitab Bukhari)..

b. Ummahatul mukminin membuka pintu rumah untuk orang yang berniat mendalami sunnah Rasulullah saw.

Dari Abu Bakar bin Abdurrahman dikatakan bahwa Marwan mengutusnya kepada Ummu Salamah untuk menanyakan perihal seorang laki-laki yang mendapatkan pagi dalam keadaan junub, apakah sah puasanya? Ummu Salamah menjawab: "Rasulullah saw pernah bangun pagi dalam keadaan junub karena bersetubuh, bukan karena mimpi. Namun beliau tidak berbuka dan tidak mengqadha (mengganti) puasanya." (HR. Muslim) (Kitab Muslim).

4. Keterlibatan wanita dalam amar ma'ruf nahi munkar

Zaid bin Aslam mengatakan bahwa Abdul Malik bin Marwan mengirimkan peralatan rumah tangga untuk Ummu Darda. Pada suatu malam, Abdul Malik bangun, lalu memanggil pesuruhnya. Melihat pelayan itu agak lambat melaksanakan perintahnya, Abdul Malik mengutuknya. Keesokan harinya, Ummu Darda berkata kepada Abdul Malik: "Tadi malam aku dengar kamu mengutuk pelayanmu ketika kamu memanggilnya. Aku pernah mendengar Abu Darda berkata: "Rasulullah saw telah bersabda bahwa orang-orang yang suka mengutuk tidak akan mendapat syafa'at dan tidak bisa menjadi saksi pada hari kiamat...." (HR Muslim) (Kitab Bukhari).

Thabrani dari Yahya bin Abu Sulaim berkata: "Aku pernah melihat Samra' binti Nuhaik dia sempat bertemu Rasulullah saw memakai baju tebal dan selendang tebal. Di tangannya ada cambuk yang dia gunakan untuk memukul orang-orang. Dia aktif menjalankan tugas 
amar ma'ruf dan nahi munkar.” (HR. Thabrani) (Kitab Majma' AzZawaid).

5. Keterlibatan wanita berbakti dalam bidang kebajikan dan pengabdian sosial.

a. Menjamu orang baik dan terhormat

Dari Fatimah binti Qais dikatakan: "Rasulullah saw berkata kepadaku, "Pindahlah kamu ke rumah Ummu Syarik. Ummu Syarik adalah seorang wanita kaya raya dari kaum Anshar, banyak membelanjakan uangnya pada jalan Allah dan sering disinggahi oleh para tamu. "Aku menjawab, "Akan aku lakukan." Tapi kemudian beliau berkata,"Jangan kamu lakukan, sebab Ummu Syarik adalah seorang wanita yang banyak tamu!" Dalam satu riwayat disebutkan: "Sesungguhnya Ummu Syarik sering didatangi oleh para Muhajirin pertama." (HR Muslim) (Kitab Bukhari).

b. Menyumbangkan mimbar pada masjid

Dari Jabir bin Abdullah ra, dia berkata bahwa seorang wanita Anshar berkata kepada Rasulullah saw: "Wahai Rasulullah, maukah engkau aku buatkan sesuatu yang engkau bisa duduk di atasnya?.... lalu wanita itu membuatkan mimbar untuk beliau. Apabila hari Jum'at tiba, Nabi saw duduk di atas mimbar tersebut." (HR Bukhari) (Kitab Bukhari).

c. Membersihkan masjid

Dari Abu Hurairah dikatakan bahwa seorang laki-laki atau seorang wanita berkulit hitam pernah menyapu masjid. Dalam satu riwayat menurut Bukhari disebutkan: "Aku tidak melihat selain bahwa dia adalah seorang wanita. Kemudian tukang sapu itu meninggal. Nabi saw menanyakan perihal tukang sapu itu. Para sahabat menjawab, "Dia sudah meninggal." Nabi saw berkata, "Kenapa kalian tidak memberitahukan hal itu kepadaku? Sekarang tunjukkanlah kepadaku di mana kuburannya!.” Kemudian Nabi saw pergi ke pusara tukang sapu itu, lalu menyalatkannya." (HR Bukhari dan Muslim) (Kitab Muslim). 
d. Memberikatan perawatan

Aisyah ra berkata bahwa Sa'ad terkena panah pada waktu peperangan Khandaq. Lalu Nabi saw membuat tenda di masjid agar beliau dapat menjenguknya dari dekat (HR. Bukhari) (Kitab Muslim). Hafizh Ibn Hajar berkata: "Ibnu Ishaq menyebutkan bahwatendaitu milik RufaidahAl-Aslamiyah, seorang wanita yang biasa merawat orang luka." Rasulullah saw berkata: "Inapkanlah dia di tenda Rufaidah itu agar aku dekat menjenguknya" (Kitab Bukhari).

6. Beberapa contoh kegiatan wanita dalam bidang sosial tanpa bertemu dengan kaum laki-laki

a. Berkorban untuk kebajikan

Dari Aisyah ra dikatakan bahwa beberapa istri Nabi saw bertanya kepada beliau, "Siapakah di antara kami yang paling cepat menyusul engkau?" Nabi saw menjawab, “Orang yang paling panjang tangannya di atara kalian." Lalu mereka mengambil sepotong bambu untuk mengukur panjang hasta mereka. Ternyata Saudah yang paling panjang tangannya. Akhirnya tahulah kami setelah wafatnya Zainab binti Jahsy bahwa panjang tangan itu maksudnya banyak bersedekah. Zainab adalah orang yang paling dahulu di antara kami menyusul beliau dan dia sangat senang bersedekah. Dalam satu riwayat disebutkan: "Dia (Zainab) paling suka mengorbankan dirinya untuk pekerjaan yang dengan pekerjaan itu dia dapat bersedekah dan mendekatkan diri kepada Allah." (HR. Bukhari Muslim) (Kitab Bukhari). Dari Jabir, dia berkata: "... Lalu Rasulullah saw segera menemui istri beliau, Zainab yang saat itu sedang menyamak kulit."(HR Muslim) (Kitab Muslim)

b. Membantu tetangga

Dari Asma' binti Abu Bakar ra, dia berkata: "Az-Zubair mengawiniku. Di bumi ini dia tidak memiliki harta atau hamba atau apapun kecuali unta dan kudanya. Akulah yang memberi makan kudanya, menimba air, menjahit tempat airnya (yang terbuat dari kulit), dan membuat adonan. Tetapi aku tidak bisa membuat roti 
dengan baik. Karena itu, para tetanggaku dari kaum Ansharlah yang biasa membuatkan roti untukku. Mereka adalah para wanita yang tulus...." (HR Bukhari dan Muslim) (Kitab Muslim).

c. Meminjamkan pakaian untuk acara tertentu

Dari Abdul Wahid bin Aiman, dia berkata, "Suatu hari aku menemui Aisyah ra. Dia memakai kebaya bahan katun seharga lima dirham. Dia berkata,”... pada zaman Rasulullah saw dahulu, baju ini seringkali dipinjam oleh wanita-wanita di Madinah untun berdandan." (HR Bukhari) (Kitab Muslim).

d. Ikut serta dalam bidang pendidikan dan pengentasan buta aksara Dari Asy-Syifa' binti Abdullah, dia berkata: "Nabi saw datang menemui kami. Ketika itu aku berada di samping Hafshah. Beliau berkata, "Bersediakah kamu mengajari Hafshah cara menjampi luka lambung seperti halnya kamu pernah mengajarinya cara menulis?" (HR Ahmad dan Abu Daud) (Kitab Bukhari).

\section{Kesimpulan}

Penulis meyakini bahwa pengembalian wanita kepada misi kefeminisannya yang murni, bukan berarti menutup pintu aktivitas perempuan di wilayah publik termasuk di antaranya untuk kegiatan sosial. Namun dengan tetap mengutamakan tugas utamanya sebagai wanita dengan tidak melupakan tugas-tugas lain di wilayah publik. Selain itu, meneladani kaum wanita pada masa nabi (shahabiyah), maka wanita yang berperan dalam wilayah publik seharusnya tidak melupakan etika-etika Islam dalam bermasyarakat seperti dalam hal berpakaian, berbicara dan beraktivitas, demi terwujudnya masyarakat yang sehat jiwanya dan bermoral.

\section{DAFTAR PUSTAKA}

Abu Syuqqah. 1999. Kebebasan Wanita. Jilid 1. Jakarta: Gema Insani Press.

Abu Syuqqah. 2000. Kebebasan Wanita. Jilid 2, cet. 3. Jakarta: Gema Insani Press.

Al-Qaradhawi, Yusuf. 2007. Kita dan Barat. Jakarta: Pustaka Al-Kautsar.

Arif, Syamsuddin. 2006. Menyikapi Feminisme dan Isu Gender. Al-Insan. 
130 Egalita Jurnal Kesetaraan dan Keadilan Gender, Volume VI No. 2 Juni 2011, hlm. 114-130

Volume ke-2, Nomor 3: 93.

Dahlan, et al. 2003. Ashabun Nuzul Latar Belakang Historis Turunnya AlQuran. Bandung: CV. Diponegoro.

http://www.bjaist.ac.jp/ helianti/edisi21/topik21.html, diakses Jum'at 14 oktober 2011, jam 13. 41.

Muslikhati, Siti. 2004. Feminisme dan Pemberdayaan Perempuan dalam Timbangan Islam. Jakarta: Gema Insani Press. 